\title{
MUZAKKI DAN KRITERIANYA DALAM TINJAUAN FIKIH ZAKAT
}

\author{
Isnawati Rais \\ Majelis Ulama Indonesia Pusat
}

\begin{abstract}
Abstrak: Zakat adalah ibadah yang bercorak sosial-ekonomi, merupakan bagian dari sistem moneter dan sosial Islam yang sangat penting dalam pemberdayaan, harmonisasi, dan kesejahteraan umat. Kedudukannya yang sangat strategis ini menuntut umat Islam untuk benar-benar memperhatikan danmengupayakanpenghimpunandanpemberdayaannya secara maksimal, sehingga mampu mengatasi berbagai kesenjangan dan persoalan ekonomi dan sosial masyarakat Islam.
\end{abstract}

Kata Kunci: zakat, muzakki, fikih zakat

\section{Pendahuluan}

Bersamaan dengan perkembangan kehidupan sosial dan perekonomian masyarakat akhir-akhir ini terutama masyarakat Islam, maka pembicaraan tentang zakat yang merupakan rukun Islam yang bercorak sosial ekonomi ini semakin menjadi fokus perhatian para ahli dan pihak-pihak yang berkompeten. Hal itu tidak lain karena zakat, walaupun selalu dibahas di dalam pokok bahasan ibadat, merupakan bagian yang tidak terpisahkan dari salat, namun sebenarnya juga merupakan bagian dari sistem keuangan, ekonomi, sosial, politik dan moral Islam yang sangat penting dalam upaya membangun ekonomi umat dan menjaga keseimbangan antara yang kaya dan yang miskin, sehingga persoalan ini, selain dibahas dalam konteks ibadat, juga telah menjadi bahasan dalam buku-buku hukum, ekonomi dan bidang keislaman lainnya.

Karena eratnya hubungan zakat dengan persoalan sosial-ekonomi 
umat, maka ketika membicarakan ekonomi umat tidak bisa dilepaskan dari persoalan zakat. Hal itu, karena selain merupakan salah satu rukun Islam dan bagian dari ibadah, zakat juga sebagai salah satu sumber keuangan dalam Islam yang sangat penting artinya untuk membebaskan kaum miskin dari kesulitan dan kepapaan, serta sangat berguna untuk pemberdayaan umat. Selain itu tujuan terpenting dari zakat adalah mempersempit ketimpangan ekonomi di dalam masyarakat sampai seminimal mungkin, sehingga terjalin kehidupan yang harmonis di antara kalangan yang berbeda keadaan ekonominya ini. Sehubungan dengan ini Rasulullah menjelaskan bahwa: "zakat merupakan harta yang dipungut dari orangorang kaya dan diberikan kepada yang miskin".

Dari penjelasan Rasulullah ini nyatalahlah bahwa kebijakan pendistribusian harta sangat penting artinya dalam menjaga keseimbangan, kesatuan hati dan kekuatan suatu masyarakat. Karena itu, perlu ditumbuhkan kesadaran kepada semua pihak yang berkompeten, terutama para ulama, pemerintah dan orang yang diberikan rezki lebih oleh Allah (orang kaya) untuk memperhatikan dan melaksanakan aturan agama ini dengan sebaikbaiknya. Disebutkan secara khusus ulama, pemerintah dan orang kaya, karena ketiga komponen ini mempunyai posisi yang sangat menentukan untuk terlaksananya kewajiban ini. Masih banyaknya hal yang belum disepakati dalam persoalan zakat, seperti siapa saja yang wajib berzakat, apa saja yang wajib dizakatkan, bagaimana caranya, ketentuan nisab dan haulnya, dan persoalan kekayaan dan penghasilan-penghasilan bentuk baru, yang belum dikenal pada masa yang lalu dan berbagai persoalan lain yang terkait, menjadi domainnya para ulama untuk merumuskannya, sehingga tidak ada lagi keragu-raguan masyarakat dalam berbagai hal itu. Di samping itu ulama juga mempunyai peran penting dalam menghimbau, mensosialisasikan dan memberikan penjelasan kepada masyarakat akan pentingnya zakat dan akibat buruk yang mungkin terjadi kalau kewajiban ini tidak dipatuhi.

Sementara itu pemerintah sebagai penguasa, mempunyai kewajiban untuk mengatur dan mengawasi pelaksanaan zakat sehingga berjalan dengan baik sesuai dengan aturan. Pemerintah berkewajiban memungut dari orang yang wajib mengeluarkan zakat(muzakki) dan memberikan kepada orang yang berhak menerima (mustahiq)-nya. Hal ini antara lain 
dijelaskan dalam QS.9:60, menyangkut 'amil dan mustahiq lainnya, dan QS 9:103, mengenai perintah memungut zakat. Dalil yang paling tegas dalam masalah ini adalah tindakan Khalifah Abu Bakar Shiddiq memerangi orangorang yang tidak mau membayar zakat. Selain itu di dalam hadis Bukhari, Muslim dan beberapa perawi lain disebutkan bahwa Rasulullah saw., ketika mengutus Mu'az keYaman, bersabda kepadanya: "Beritahukanlah kepada mereka bahwa Allah SWT telah mewajibkan dari sebagian harta mereka untuk disedekahkan. Diambil dari orang kaya untuk diberikan kepada orang-orang yang fakir . . .. Di samping itu, di dalam berbagai riwayat ditemukan bahwa Rasulullah telah mengangkat beberapa orang untuk menjadi petugas zakat.

Selain dari ulama dan pemerintah, muzakki menjadi bagian yang tidak terpisahkan dari pelaksanaan perintah wajib zakat ini karena merekalah orang yang dibebani kewajiban untuk mengeluarkan bagian tertentu dari harta kekayaannya untuk kemudian diberikan kepada yang berhak menerimanya. Berhasil tidaknya pelaksanaan zakat, salah satunya ditentukan oleh kemampuan menghimpun muzakki, karena dana yang akan didistribusikan kepada mustahiq dalam rangka memperbaiki ekonomi umat berasal dari mereka. Hal inilah yang akan menjadi fokus perhatian pada makalah ini, terutama untuk mengemukakan tentang siapa dan apa kriteria muzakki.

Untuk lebih jelasnya persoalan ini, maka berikut ini akan dibahas masalah ini secara sederhana dan beberapa hal yang terkait, seperti kedudukan zakat dalam Islam, kewajiban berzakat, siapa yang diwajibkan mengeluarkan zakat, dan ketentuan harta/kekayaan yang wajib dizakatkan. Kemudian dilengkapi dengan jenis-jenis harta kekayaan yang wajib dizakatkan.

\section{Kedudukan Zakat dalam Islam}

Zakat sebagai salah satu rukun Islam ${ }^{1}$ mempunyai kedudukan yang sangat penting, baik dalam konteks hubungan manusia dengan Allah, dengan

${ }^{1}$ Zakat adalah rukun Islam yang ketiga dari lima rukun Islam. Lihat, Asy-Syaukaaniy, Naylul authaar, (Beirut: Daar al-Fikr, t.th) Juz IV, hal. 169. Lebih lengkap hal ini dapat dilihat dalam hadis Bunial Islam 'alaa khamsin. ... 
dirinya, dengan masyarakat, dan dengan hartanya. Dalam hubungan manusia dengan Allah, zakat adalah salah satu sarana beribadah kepada Allah, yang berfungsi untuk mendekatkan diri kepada-Nya. Rasulullah menjelaskan bahwa: "Sesungguhnya Allah menolong hambanya manakala hamba itu suka menolong saudaranya". Kepatuhan membayar zakat dinyatakan sebagai tanda kualitas orang yang benar-benar beriman seperti dicantumkan dalam firman Allah pada QS.9: 18 dan 71.

Dalam hubungannya dengan diri sendiri (muzakki), zakat merupakan salah satu cara memberantas pandangan hidup materialistis, suatu paham yang menjadikan harta bukan lagi sebagai alat untuk mencapai tujuan hidup, tetapi menempatkannya sebagai tujuan hidup. Dengan demikian zakat menjaga manusia dari kerusakan jiwa, dan memebersihkannya dari sifat-sifat tercela. Zakat yang dikeluarkan oleh seorang Muslim karena patuh kepada Allah dan mencari ridha Allah, akan dapat membersihkan dan mensucikannya dari dosa dan sifat kikir.

Dengan ini jelaslah bahwa zakat mempunyai kedudukan penting bagi muzakki untuk menjadikannya bisa menjadi tuan terhadap hartanya dan bukannya menjadi budaknya harta. Karena itulah dalam QS.9:103 Allah menegaskan bahwa tujuan zakat itu adalah untuk membersihkan dan mensucikan mereka (muzakki). Pembersihan dan pensucian ini meliputi material, yaitu harta dan spritual, yaitu jiwa. Berzakat berarti membersihkan harta dari segala keburukannya, dan memeliharanya dari berbagai kemungkinan bencana yang mugkin terjadi. Sementara itu di sisi lain, zakat sangat penting artinya bagi muzakki, untuk mensucikan jiwanya dari sifat kikir, melatih diri untuk memberi dan berakhlak dengan akhlak Allah, melatih diri untuk selalu bersyukur atas segala pemberian Allah, melatih diri untuk tidak terlalu mencintai dunia, melatih diri untuk mengutamakan kekayaan batin, membangun hubungan batin dan rasa cinta sesama.

Sementara itu, zakat juga sangat penting artinya dalam menjaga harmonisasi kehidupan dalam masyarakat, dengan memperkecil jurang perbedaan ekonomi antara yang kaya dan yang miskin. Sudah menjadi sunnatullah bahwa di dalam masyarakat terdapat berbagai perbedaan antara satu dengan yang lain, termasuk dalam hal kemampuan ekonomi, 
yang melahirkan golongan ekonomi kuat dan lemah, yang biasa disebut dengan golongan kaya dan miskin. Perbedaan ini, sebetulnya sebagai batu ujian bagi kedua belah pihak, namun, apabila tidak mampu disikapi dengan bijak, maka akan menimbulkan berbagai akibat negatif dalam pergaulan dan harmonisasi hubungan, yang pada tingkat tertentu bisa menimbulkan pertentangan kelas sosial. Berbagai tindakan tidak terpuji dari kedua belah pihak bisa saja terjadi setiap saat, yang mengakibatkan terganggunya ketertiban dan terhambatnya kemajuan. Jalan keluar dari persoalan masyarakat ini adalah bagaimana menumbuhkan "getah", yang dapat mempertautkan hati antara kelas sosial yang berbeda ini. Zakat, adalah media yang disediakan oleh Islam untuk menumbuhkan getah itu. Sebagian harta orang yang kaya diambil dan disalurkan untuk menghidupkan dan memperbaiki keadaan ekonomi masyarakat miskin, sehingga kehidupan mereka semakin baik. Dengan terjalinnya hubungan lewat media ini, maka tumbuhlah rasa persaudaraan dan keinginan saling menghormati dan saling membantu.

Selain itu, zakat adalah media untuk menumbuhkan kesadaran di dalam diri manusia, bahwa harta benda yang mereka punyai bukanlah milik penuh mereka, tetapi merupakan amanat Allah yang dititipkan kepada manusia untuk mengelolanya, untuk diambil manfaatnya dan dipergunakan sesuai dengan ketentuan Allah, pemilik yang sebenarnya. Dengan demikian, manusia hanya mempunyai hak pakai dan hak guna, yang harus disesuaikan dengan ketentuan Allah. Di antara ketentuan itu adalah bahwa harta kekayaan itu selain berfungsi untuk memenuhi kebutuhan pribadi, juga mempunyai fungsi sosial, untuk kepentingan umum, kepentingan masyarakat, dan kepentingan perjuangan agama. Di samping itu zakat juga berfungsi membersihkan harta yang boleh jadi saja tanpa disadari tercampur dengan yang kurang jelas kehalalannya. Tetapi perlu ditegaskan bahwa harta yang jelas kotornya tidak bisa dibersihkan dengan zakat.

Dengan penjelasan di atas nyatalah pentingnya kedudukan zakat bagi kehidupan manusia dalam ajaran Islam, baik dalam hubungannya dengan pelaksanaan rukun Islam, ibadah yang dilaksanakan untuk mendekatkan diri kepada Allah, ataupun untuk kepentingan masyarakat, memperbaiki ekonomi umat, membangun hubungan harmonis dalam kehidupan ber- 
masyarakat, memperbaiki pola fikir dan pola pandang terhadap harta, sehingga manusia mampu menyadari bahwa harta bukanlah segala-galanya dan bukan pula tujuan hidup ini.

\section{Kewajiban Berzakat}

Menurut Sayyid Sabiq, zakat, ialah nama dari suatu hak Allah Ta'ala yang dikeluarkan seseorang kepada fakir miskin. Dinamakan zakat, karena di dalamnya terkandung harapan untuk beroleh berkah, membersihkan jiwa dan memupuknya dengan berbagai kebajikan. ${ }^{2}$

Zakat yang merupakan salah satu rukun Islam, telah disebutkan beriringan dengan salat pada banyak tempat di dalam al-Qur'an. Menurut Sayyid Sabiq, jumlahnya ada 82 ayat $^{3}$. Sedangkan menurut Yusuf Qardhawi, jumlah ini terlalu dibesar-besarkan, kecuali kalau yang dimaksud, termasuk kata-kata lain yang sama maksudnya dengan zakat, seperti, infaq, alma'un, tha'am al-miskin dan lain-lain, memang jumlahnya berkisar antara 32 sampai 82 tempat. ${ }^{4}$ Telah menjadi kesepakatan (ijma') kaum muslimin berdasarkan Al-Qur'an dan sunnah Rasul bahwa hukum zakat adalah wajib. Di antara dalil wajibnya itu adalah:

Pertama, ayat-ayat al-Qur'an, khususnya yang turun di Madinah dengan secara tegas menetapkan hukum wajibnya zakat dan memberikan instruksi pelaksanaannya secara jelas, misalnya dalam QS. 2: 43, 83 dan 110 yang menyatakan: "Dirikanlah oleh kalian salat dan bayarkanlah zakat. Kemudian beberapa ayat dalam surat at-Taubah telah memberikan beberapa penjelasan penting tentang zakat, misalnya pada ayat ke sebelas dijelaskan bahwa ada tiga hal yang dapat menghindarkan orang musyrik dari dibunuh, yaitu taubat dari syirik, mendirikan salat dan membayarkan zakat; pada ayat ke 34-35, Allah mengancam orang yang menimbun emas dan perak yang tidak mengeluarkan zakatnya dengan siksaan yang berat; pada ayat ke 60 dijelaskan para mustahiq zakat; dan pada ayat

${ }^{2}$ Sayyid Sabiq, Fiqh as-Sunnah,(Beirut: Daar al-Fikr, 1397/1977) Jld I, hal.276

${ }^{3}$ Ibid.

${ }^{4}$ Yusuf Qardhawi, Fiqhu al-zakah, (Beirut: Muassasah al-Risaalah, 1420H/1999) Jilid I, hal.42. 
ke 71 dijelaskan pula tentang zakat merupakan salah satu jalan untuk mendapatkan rahmat Allah di samping beberapa hal lainnya. Sedangkan di ayat ke 103, diperintahkan kepada Rasulullah untuk memungut zakat dari kekayaan orang mukmin.

Kedua, di dalam hadis-hadis Rasulullah juga banyak dijelaskan tentang kewajiban zakat dan aturan pelaksanaannya. Perintah itu antara lain diberikan Rasulullah kepada Mu'az bin Jabal ketika ia ditugaskan untuk menjadi qadhi di Yaman: “. . .Jika ini telah mereka ta'ati, sampaikanlah bahwa Allah telah mewajibkan zakat pada harta benda mereka yang dipungut dari orang-orang kaya dan diberikan kepada orang-orang miskin di antara mereka. .." (HR. Jamaah) ${ }^{5}$. Dalam hadis yang diriwayat oleh Thabrani dari Ali r.a disebutkan tentang wajibnya zakat pada harta orangorang kaya, untuk melapangi orang-orang miskin. Di akhirya diingatkan akan azab Allah bagi yang mengengkari. Dalam beberapa hadis juga dijelaskan tentang nisab dan kadar yang harus dikeluarkan. Selain itu, hadis "Buniyal Islaam 'alaa khamsin. ..”yang salah satunya adalah kewajiban membayar zakat juga menjadi dasar yang kuat tentang kewajiban zakat ini.

Ketiga, kewajiban membayar zakat ini semakin jelas ketika Islam memberikan peringatan dan ancaman yang keras kepada orang yang tidak mau membayarnya, bahwa mereka akan diazab di akhirat dengan azab yang pedih, seperti akan distrika dengan emas perak yang dipanaskan di nereka pada kening, pinggang dan punggung (QS.9:34-35), harta itu akan dikalungkan di leher (QS.3:180). Selain itu, dalam beberapa hadis juga dijelaskan tentang hal ini, antara lain HR. Bukhari dari Abu Hurairah: "Siapa yang dikaruniai oleh Allah kekayaan tetapi tidak mengeluarkan zakatnya, maka di hari kiamat ia akan didatangi oleh seelor ular jantan gundul, yang sangat berbisa dan sangat menakutkan dengan dua bintik di atas kedua matanya, lalu melilit dan mematuk lehernya sambil berteriak: "saya adalah kakayaanmu, saya adalah harta yang kamu timbun". Nabi kemudian membacakan ayat QS.3:180. ... Di samping itu, di dunia mereka juga akan mendapatkan hukuman. Rasulullah bersabda: "Orang-orang yang tidak mau mengeluarkan zakat akan ditimpa kelaparan dan kemarau yang

${ }^{5}$ Asy-Syaukaaniy, Op. cit., hal. 170. 
panjang”. (HR. Tabrani dalam al-Awsath). Senada dengan ini: "Bila(orangorang) kampung tidak berzakat, Allah akan menahan hujan"

Keempat, selain memberi ancaman, Rasulullah saw juga menetapkan hukuman bagi orang yang tidak membayar zakat. Hukuman itu antara lain ditetapkan dalam hadis yang diriwayatkan oleh Ahmad, Nasa'i dan lainlain: “. . Orang yang membayar zakat untuk memperoleh pahala, maka ia akan mendapatkan pahala itu, sedangkan orang yang tidak membayarnya maka kita akan memungut zakatnya dengan paksa dan ditambah separuh hartanya. Ini merupakan ketentuan tegas dari Tuhan kita (Allah),. . .” Selain memungut dengan paksa dengan denda saparuh harta, orang-orang yang tidak mau membayar zakat dalam keadaan tertentu, seperti jumlah mereka banyak dan memiliki kekuatan untuk melawan, maka Rasul memerintahkan untuk memerangi mereka. Lihat HR Bukhari Muslim dari Ibu Umar ra: Rasulullah bersabda: "Saya diperintahkan untuk memerangi mereka sampai mereka bersaksi bahwa tidak ada Tuhan selain Allah dan bahwa Muhammad Rasulullah, mendirikan salat dan membayar zakat. Apabila mereka telah melaksanakan hal itu, mereka telah memelihara darah dan harta mereka dari saya ..."

Dalil-dalil yang kuat dari Al-Qur'an dan hadis inilah yang mendasari kesepakatan umat Islam untuk wajibnya zakat, sehingga para sahabat sepakat memerangi orang-orang yang tidak mau berzakat atau pembangkang zakat. Disepakati pula bahwa siapa yang mengengkari kewajiban zakat dihukum kafir, diberlakukan kepada mereka hukum murtad, yang kalau tidak mau bertaubat maka dibunuh. Kecuali kalau mereka betulbetul tidak tahu kewajiban itu $^{8}$

${ }^{6}$ Yusuf Qardhawi, Op. cit., hal. 76. Beberapa hadistentang ancaman hukuman ini dapat pula dilihat pada Asy-Syaukani, ibid., hal. 172-173

${ }^{7}$ Diskusi tentang hal ini dapat dilihat dalam Asy-Syaukani, Ibid., hal 175-177. Di sini dijelaskan pula penegasan Abu Bakar: “ Demi Allah saya akan memerangi orangyang membeda-bedakan antara salat dan zakat. Sesungguhnya zakat adalah kewajiban mengenai harta, dan demi Allah, seandainya mereka tidak hendak menyerahkan seekor anak kambing (dalam riwayat lain tali pengikat unta) yang pernah mereka serahkan kepada Rasulullah saw., akan saya perangi mereka, karena tidak membayarkan itu".

${ }^{8}$ Wahbah az-Zuhayli, Al-Fiqh al-Islaamiyah wa adillatuh, (Damsyiq: Daar al-Fikr, 1989) Juz II, hal. 734 . 


\section{Yang Wajib Berzakat(Muzakki)}

Persoalan yang sangat terkait dengan kewajiban zakat adalah atas siapa diwajibkan berzakat itu. Inilah sebenarnya yang menjadi inti dari pembahasan tema ini. Orang ${ }^{9}$ yang wajib berzakat disebut dengan Muzakki. Telah disepakati oleh umat Islam bahwa zakat hanya diwajibkan kepada seorang muslim, merdeka, dewasa yang berakal, yang memiliki kekayaan dalam jumlah tertentu dengan syarat tertentu. ${ }^{10}$ Ketentuan ini ada yang disepakati dan ada pula yang tidak.

Mengenai ketentuan yang pertama, para ulama telah sepakat bahwa zakat tidak diwajibkan kepada non muslim. Dasar pendapat mereka ini adalah hadis shahih yang menjelaskan tentang instruksi nabi kepada Mu'az bin Jabal ketika beliau mengutusnya ke Yaman: “. . .Yang pertama yang harus kamu lakukan adalah mengajak mereka agar meyakini bahwa Tiada Tuhan selain Allah dan Muhammad adalah RasulNya. Apabila mereka menyambut seruanmu, maka ajarkanlah bahwa Allah mewajibkan mereka salat lima kali dalam sehari. Dan bila mereka mengerjakannya, maka barulah kamu beritahukan kepada mereka bahwa Allah mewajibkan mereka berzakat, yang dipungut dari orang kaya mereka dan diberikan kepada orang yang miskin." Dengan ini jelaslah bahwa kewajiban zakat ini terkait dengan keislaman seseorang, dan ia merupakan salah satu dari lima landasan tempat berdirinya bangunan keislaman itu, yaitu syahadat, salat, zakat, puasa dan haji ke Baitullah. Karena itu tidak diwajibkan bagi orang yang tidak Islam.

Para ulama juga sepakat bahwa zakat hanya diwajibkan bagi Muslim yang merdeka. Zakat tidak wajib atas budak, karena budak tidak memiliki apa-apa, bahkan ia sendiri adalah milik tuannya. Kalaupun ia memiliki

${ }^{9}$ Termasuk dalam pengertian orang di sini adalah badan/lembaga yang dimiliki oleh orang Islam.

${ }^{10}$ Yusuf Qardhawi, op. cit., hal. 95. Di dalam Kitabul Fiqh 'alal Mazaahibil arba'ah dijelaskan bahwa Syarat diwajibkan berzakat itu adalah, baligh, berakal, dan Islam. Untuk anak-anak dan orang gila yang mempunyai harta menurut tiga Imam kecuali Hanafiyyah, wajib dikeluarkan zakatnya, tetapi kewajiban mengeluarkan dibebankan kepada walinya. Menurut Hanafiyyah tidak wajib zakat. Sedangkan harta orang kafir tidak wajib zakat. Abdurrahman al-Jazayri, Kitaabul fiqhi 'alal mazaahibil arba'ah, (Beirut: Daar al-Rasyaad al-Hadiitsah,t.th) Juz. I, hal. 590-591. 
sesuatu, maka itu bukanlah pemilikan yang sempurna (penuh).

Sementara itu, para ulama berbeda pendapat tentang harta anakanak dan orang gila, ada yang berpendapat tidak wajib, dan ada yang sebaliknya. Beberapa ulama seperti Abu Ja'far al-Baqir, Hasan, Mujahid dan lain-lain berpendapat bahwa harta anak-anak dan orang gila tidak wajib dikeluarkan zakatnya. Mereka beralasan: ${ }^{11}$ Pertama, zakat adalah ibadah mahdhah seperti salat, dan ibadah ini perlu niat, yang tidak dipunyai oleh anak-anak atau orang gila, dan kalaupun mereka bisa melakukannya, tidaklah dianggap. Karena itu, ibadat tidak wajib atas mereka, dan mereka tidak dikhithab dengannya.

Kedua, alasan di atas, menurut mereka didukung oleh hadis rufi'al qalam 'an tsalaatsattin: 'anish shabiyyi hatta yablugha, 'anin naa'imi hatta yastayqazha, wa 'anil majnuuni hattayfiiqa. Terangkatnya pena berarti bebas dari tuntutan hukum, karena hukumnya hanya dibebankan kepada orang yang memahami maksud hukum, sedangkan tiga golongan yang disebutkan dalam hadis tidak memahami maksud tersebut.

Ketiga, dalil lain menurut mereka adalah firman Allah dalam QS. 9:103. Di sini dijelaskan bahwa tujuan dari perintah pemungutan zakat itu adalah untuk membersihkan dan mensucikan dari dosa, sedangkan anakanak dan orang gila tidak berdosa. Karena itu, tentu mereka tiak termasuk dalam tuntutan ayat ini.

Keempat, selain itu, kemashlahatan yang menjadi perhatian Islam dalam setiap penetapan hukumnya, menurut mereka tidak akan tercapai dengan mewajibkan zakat kepada harta mereka ini, karena ketidakmampuan mereka mengelola harta, maka penarikan zakat dari tahun ketahun dikhawatirkan akan menghabiskan harta mereka dan menyebabkan mereka miskin.

Sementara itu Jumhur ulama dari kalangan sahabat, tabi'in dan orang yang sesudah mereka berpendapat bahwa harta anak-anak dan orang gila wajib dikeluarkan zakatnya. Alasan mereka adalah ${ }^{12}$ : (1) Nash

\footnotetext{
${ }^{11}$ Ibid., Juz I, hal. 105-108

${ }^{12}$ Ibid., hal. 108-111
} 
ayat dan hadis yang mewajibkan zakat bersifat umum, yang mencakup pada semua harta orang kaya, tanpa mengecualikan anak-anak dan orang gila. (2) Hadis riwayat Syafi'i dari Yusuf bin Mahak bahwa Rasululullah bersabda: "Terimalah/Ambillah oleh kalian zakat dari harta seorang anak yatim (yang kaya), atau harta kekayaan anak-anak yatim yang tidak mengakibatkan harta itu habis. (3) Selain itu mereka beralasan dengan tindakan para sahabat, seperti Umar, Ali, Abdullah bin Umar, Aisyah dan Jabir bin Abdullah yang mewajibkan zakat atas kekayaan anak-anak. (4) Kemudian mereka juga melihat dari sisi makna dari diwajibkannya zakat, yang menurut mereka adalah untuk membantu orang yang membutuhkan di samping untuk mensyukuri nikmat Allah, karena itu anak-anak dan orang gila, bila memang kaya tidak terlepas dari kewajiban zakat ini.

Setelah memperhatikan semua alasan dari kedua belah pihak, maka Yusuf Qardhawi berpendapat bahwa yang mewajibkan zakat harta anak dan orang gila lebih kuat dalilnya ${ }^{13}$. Lebih lanjut ia menegaskan bahwa kekayaan anak-anak dan orang gila wajib zakat, karena zakat merupakan kewajiban yang terkait dengan kekayaan bukan dengan orang, yang tidak gugur karena pemiliknya masih anak-anak atau orang gila.

Dengan paparan di atas jelaslah bahwa untuk penentuan muzakki itu tidaklah terlalu sulit, karena kriterianya sangat sederhana sekali. Telah dijelaskan bahwa muzakki itu adalah seorang muslim atau lembaga yang dimiliki oleh orang Islam yang memiliki harta yang diwajibkan zakat, baik sudah dewasa atau tidak, berakal atau tidak.

Untuk mempermudah pengidentifikasian terhadap muzakki dapat pula dibantu dengan adanya beberapa ketentuan terhadap harta yang akan dikenai wajib zakat. Secara ringkas hal itu akan dikemukakan pada bagian berikut.

\section{Harta Yang dikenai Wajib Zakat}

Tidak semua harta yang dimiliki seseorang dihitung sebagai kekayaan yang dikenai wajib zakat. Menyangkut hal ini ada beberapa batasan

\footnotetext{
${ }^{13}$ Pandangan dan analisa Qardhawi mengenai hal ini dapat dilihat ; Ibid.,hal. 111-112.
} 
dan ketentuan yang perlu diperhatikan, yaitu bahwa harta yang diwajibkan zakat itu adalah: (1) Milik Penuh, artinya kekayaan itu berada di bawah kontrol dan kekuasaan si pemilik, sehingga memungkinkannya untuk mempergunakan dan mengambil seluruh manfaat harta itu. (2) Berkembang, artinya kekayaan itu dikembangkan dengan sengaja atau mempunyai potensi untuk berkembang. (3) Cukup satu nisab, artinya harta itu mencukupi jumlah minimal yang diwajibkan zakat padanya, misalnya 85 gram emas, 5 ekor unta, 30 ekor sapi dan lain-lain. (4) Lebih dari kebutuhan pokok biasa, seperti untuk makan, pakaian, tempat tinggal, kendaraan, sarana mencari nafkah dan lain-lain. (5) Bebas dari hutang, artinya harta yang sudah cukup senisab itu harus dihitung di luar hutang. (6) Berlalu satu tahun (dua belas bulan Qamariyah). Syarat satu tahun ini, tidak untuk semua kekayaan yang wajib zakat, tetapi hanya untuk ternak, uang, perdagangan/ perusahaan. Sedangkan zakat pertanian, harta qarun, barang tambang, dan semua yang dikategorikan pendapatan, tidaklah disyaratkan satu tahun.

Beberapa ulama kontemporer (zaman sekarang), seperti Abu Zahrah, Abdul Wahab Khallaf, dan Abdurrahman Hasan dengan mengutip pendapat para ulama fikih terdahulu, mengelompokkan harta/ kekayaan kepada tiga kategori, yaitu: (1) Kekayaan yang dimiliki untuk pribadi, misalnya rumah untuk tempat tinggal pemiliknya, bahan makanan yang disimpan untuk kebutuhan pemilik. Ini tidak wajib dikeluarkan zakatnya. (2) Kekayaan yang dimiliki untuk memperoleh keuntungan atau sifat benda itu memberikan keuntungan. Kekayaan seperti ini wajib dikeluarkan zakatnya menurut kesepakatan ulama. (3) Kekayaan yang tidak terlalu jelas fungsinya, apakah semata sebagai kebutuhan ataukah untuk dikembangkan untuk memperoleh keuntungan, seperti perhiasan dan ternak yang untuk dipekerjakan sekaligus dikembang-biakkan. Dalam masalah ini ulama berbeda pendapat. ${ }^{14}$

Dengan memahami secara tepat harta kekayaan yang dikenai wajib zakat, akan memudahkan setiap muslim untuk mengenali dirinya sendiri, apakah ia termasuk orang yang dibebani wajib zakat atau tidak dan berapa

14 Lebih lengkap menyangkut persoalan ini dapat dilihat pada; ibid., hal. 476-477. 
zakat yang harus dikeluarkannya. Bagi para petugas, hal ini juga akan sangat membantu untuk memudahkan pensosialisasian dan pelaksanaan tugas menghimpun para muzakki.

\section{Jenis Harta Kekayaan Yang Wajib Dikeluarkan Zakatnya}

Selain hal-hal yang telah dikemukakan sebelumnya, persoalan yang menyangkut jenis harta yang wajib dikeluarkan zakatnya tidak kalah pentingnya untuk dikemukakan terkait dengan tema ini, karena menyangkut hal ini masih terdapat banyak perbedaan pendapat, terutama pada kekayaan yang tidak ditemukan nash secara sharih menyebutkannya. Sementara itu kita tahu bahwa kemajuan umat manusia telah membuat mereka mendapatkan kekayaan tidak hanya dengan jalan dan cara yang biasa ditempuh umat pada masa lalu. Dengan pemaparan ini diharapkan semakin jelaslah siapa saja yang dibebani kewajiban zakat dan berapa besar kewajiban mereka.

Kalau kita perhatikan ayat-ayat yang membicarakan tentang kewajiban zakat, maka ada beberapa jenis kekayaan yang disebutkan dan diperingatkan untuk dikeluarkan zakatnya, yaitu: emas dan perak (QS. 9:34), tanaman dan buah-buahan (QS. 6:141), usaha perdagangan dan lain sebagainya (QS.2:267) dan barang-barang tambang dan rikaz, yang dikeluarkan dari perut bumi (QS. 2:267). Perintah ini tidak langsung disertai dengan berbagai ketentuan pelaksanaannya. Ketentuannya dijelaskan oleh Sunnah. Kemudian selain itu, disebutkan pula kewajiban zakat pada binatang ternak. Berdasarkan dalil-dalil ini, maka dalam kitab-kitab fikih inilah macam-macam kekayaan yang wajib dikeluarkan zakatnya.

Namun demikian perkembangan kehidupan manusia dan sumber penghasilan mereka yang semakin beragam mengharuskan para ulama berusaha untuk mencarikan ketentuan hukumnya, supaya ada kepastian hukum yang membawa kepada ketenangan dan keadilan. Hal ini sangat penting, karena timbul banyak pertanyaan tentang apakah penghasilan yang besar dan terus berkembang perlu dikeluarkan zakatnya? Atau apakah zakat itu hanya berlaku pada apa yang telah ditetapkan sebelumnya? Hal ini tentu perlu jawaban. Sejumlah ulama kontemporer, seperti Muhammad 
Abu Zahrah, Abdul Wahab Khalaf, Muhammad Yusuf Qardhawi dan lainlain, dengan memperhatikan dalil dan pendapat para ulama telah mencoba memberikan jawaban terhadap berbagai persoalan ini. Mereka menjelaskan bahwa kekayaan yang telah memenuhi ketentuan yang telah disebutkan sebelumnya wajib dikeluarkan zakatnya, dan itu tidak hanya terbatas pada jenis yang telah ditetapkan sebelumnya.

Menurut Yusuf Qardhawi jenis kekayaan yang wajib dikeluarkan zakatnya adalah: (1) Binatang ternak, yaitu unta, sapi, kambing, domba. Termasuk di sini perbedaan pendapat tentang kuda yang digembalakan sengaja untuk dikembang biakkan. Sedangkan kuda untuk diperdagangkan disepakati kewajiban zakatnya. (2) Emas dan perak, termasuk di sini zakat uang, zakat perhiasan dengan berbagai ketentuannya. (3) Perdagangan. (4) Pertanian. (5) Madu dan produksi hewani (sutera, susu, dan lainlain). (6) Barang tambang dan hasil laut. Termasuk disini, ma'din, kanz dan rikaz, mutiara dan lain-lain yang dieksploitasi dari laut. (7) Investasi, seperti pabrik, gedung dan lain-lain. (8) Pencarian dan profesi. (9) Saham dan obligasi. ${ }^{15}$

Inilah jenis-jenis harta kekayaan yang wajib dikeluarkan zakatnya. Pengembangan pemahaman tentang jenis harta yang wajib dikeluarkan zakatnya ini merupakan persoalan baru yang perlu disosialisasikan kepada umat Islam, terutama para amil yang akan bertugas di lapangan dan para muzakki yang dibebani wajib zakat, supaya mereka mengerti kewajibannya dan mau melakukannya. Peraturan perundang-undangan yang sudah ada tentu diharapkan akan mampu mempermudah pelaksanaanya di lapangan.

Pengembangan jenis harta yang wajib dikeluarkan zakatnya ini tentu akan sangat besar pengaruh positifnya terhadap jumlah harta zakat yang bisa dihimpun. Dan ini tentu akan punya pengaruh positif pula terhadap kesejahteraan umat, berupa perbaikan ekonomi para dhu'afa. Di samping itu lebih memungkinkan untuk menjembatani kesenjangan ekonomi umat, antara yang kaya dan yang miskin.

${ }^{15}$ Penjelasan lebih lanjut tentang masing-masing dapat dilihat dalam. Ibid., hal. 121-533. 


\section{Penutup}

Zakat adalah salah satu rukun Islam yang berbeda posisinya dibandingkan dengan rukun-rukun yang lain. Kalau rukun-rukun yang lain dilakukan lebih banyak dalam upaya membangun dan memperkokoh hubungan antara makhluq dan khaliq atau antara seorang mukmin dengan Rabbnya saja, maka zakat, di samping itu punya dimensi lain, yaitu membangun hubungan antara sesama, antara yang kaya dan yang miskin atau antara muzakki dan mustahiq. Malah lebih dari pada itu antara pemerintah sebagai pelaksana dengan muzakki dan mustahiq.

Zakat adalah ibadah yang bercorak sosial-ekonomi, merupakan bagian dari sistem moneter dan sosial Islam yang sangat penting dalam pemberdayaan, harmonisasi, dan kesejahteraan umat. Kedudukannya yang sangat strategis ini menuntut umat Islam untuk benar-benar memperhatikandanmengupayakanpenghimpunandanpemberdayaannya secara maksimal, sehingga mampu mengatasi berbagai kesenjangan dan persoalan ekonomi dan sosial masyarakat Islam.

Dalam upaya ini salah satu hal penting yang harus menjadi perhatian adalah muzakki, karena ia merupakan salah satu komponen penting untuk tercapainya cita cita menjadikan zakat sebagai salah satu sokoguru ekonomi umat. Karena merekalah yang dikenai wajib zakat. Penjelasan yang simpel dan mudah tentang kriteria muzakki, harta kekayaan, dan jenis kekayaan yang wajib dikeluarkan zakatnya, diharapkan akan dapat membantu berbagai pihak yang terkait untuk memahami bahwa muzakki itu bukan hanya petani, peternak, pedagang, pemilik emas dan perak, ataupun seorang pengusaha tambang. Tetapi muzakki itu bisa lebih banyak dan lebih beragam dari itu. Muzakki bisa saja dari pegawai, para professional, pemilik bermacam-macam aset yang disewakan, pemilik saham, pengusaha, dan lain sebagainya.

Dengan memahami kriteria muzakki ini diharapkan setiap umat Islam yang mempunyai harta akan terpanggil jiwanya untuk menghitung dan menilai sendiri, apakah dia termasuk orang yang wajib berzakat atau tidak, sehingga ia tidak lagi menunggu orang lain mengingatkan. Di samping itu, ini juga diharapkan dapat memudahkan pemerintah, khususnya lembaga amil zakat untuk menghimpun muzakki semaksimal mungkin. 


\section{Pustaka Acuan}

Asy-Syaukaaniy, Naylul authaar, Beirut: Daar al-Fikr, t.th

Sayyid Sabiq, Fiqh as-Sunnah, Beirut: Daar al-Fikr, 1397/1977.

Yusuf Qardhawi, Fiqhu al-zakah, Beirut: Muassasah al-Risaalah, 1420H/1999

Wahbah az-Zuhayli, Al-Fiqh al-Islaamiyah wa adillatuh, Damsyiq: Daar alFikr, 1989 